\title{
Evaluation of Metal Ion Extractability of Crowned Spirobenzopyrans by Molecular Dynamics Calculation
}

\author{
H. Iwamoto, H. Sakamoto, and K. Kimura * \\ Department of Applied Chemistry, Faculty of Systems Engineering, Wakayama University,
}

Sakae-dani 930, Wakayama, Japan

(Received December 21,2005; Accepted February 6,2006)

\begin{abstract}
Metal ion extractability in liquid-liquid extraction using spirobenzopyrans possessing a crown ether moiety was evaluated by molecular dynamics. It was found that a longer alkyl group attached to the spirobenzopyran ring results in greater stability in the organic phase. The same trend was observed for the model metal complex. When the crowned spirobenzopyran was complexed with an alkali metal ion, the steric energy in the aqueous phase was decreased. However, the energy was higher than that of the complex in the organic phase; as a result, the complex was more stable in the organic phase. In addition, the metal ion which forms the most stable complex depends on the ring size of the crown ether. The tendency was confirmed by the liquid-liquid extraction of alkali metal ion with the crowned spirobenzopyran. This indicates that it is possible to predict the properties of extraction reagents from their steric energy values calculated using molecular dynamics.
\end{abstract}

Key Words: spirobenzopyrans, , alkali metal ion, extraction, molecular dynamics calculation, steric energy

\footnotetext{
*kkimura@sys.wakayama-u.ac.jp
} 


\section{Introduction}

Photochromism is a phenomenon in which the absorption band of a molecule appears in a different visible region $t$ due to a structural change in the molecule by light irradiation. Well-known as the photochromic molecules spirobenzopyran, spirooxazine, and chromene are. The photochromism is reversible phenomenon: the absorption band of the photochromic compound returns to its original location as the structure change upon heating or irradiation of the different light.

Crown ethers are known to form the stable complexes in which suitably sized metal ions are captured in the cavity of the crown ether molecule. In previous papers, the authors have reported the preparation of crowned spirobenzopyrans, combining spirobenzopyrans and crown ethers, which are photochromic and stable metal complexing. ${ }^{1-4}$ These complexes exhibit properties of both spirobenzopyrans and crown ethers. When the crowned spirobenzopyrans were used as extraction reagents for an alkali metal ion in liquid-liquid extraction, there complexes were effectively extracted from the aqueous to the organic phase. The crowned spirobenzopyran exhibits the unique property photochromism in accordance with the extracted amount (Scheme 1).

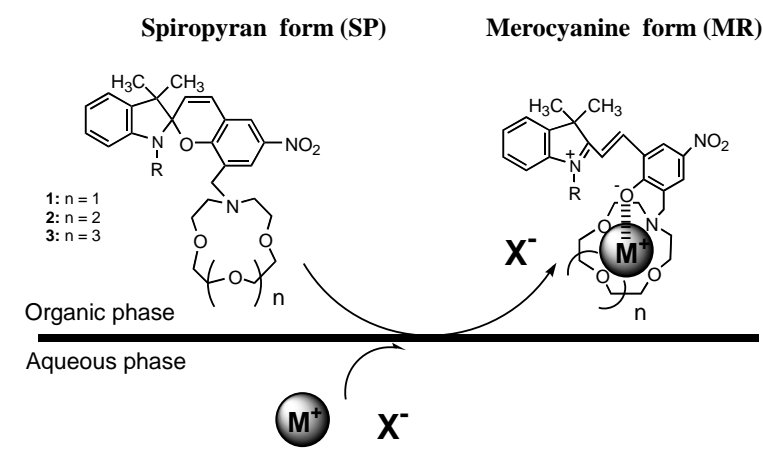

Scheme 1. Postulated mechanism for liquid-liquid extraction of metal ion with crowned spirobenzopyran derivatives.

In recent years, the processing abilities of computers have dramatically been improved. Thus, high-level molecular modeling, which was formerly considered impossible, has became a reality. Molecular simulation methods for evaluating and predicting the structures and properties of materials include molecular mechanics (MM), Monte Carlo (MC), and molecular dynamics (MD). Among these, the molecular dynamics method is widely used. This is a time-evolution calculation of the MM method, in which the potential energy functions of classical mechanics and Newton's equations of motion are simultaneously solved to determine time-dependent changes in the structure of a molecular assembly.

For a metal complex, it is necessary to obtain molecular force-field parameters for evaluation of the interaction between the metal atom and the extraction reagent molecule. However, these contain large perturbations and approximations; thus, they may not be physically meaningful constants. In addition, when we determine dynamic constants experimentally, it is necessary to isolate and purify the metal. In many cases, however, the stoichiometric relationship may be different between those in the isolated state and in the solution state. There are also cases in which several isomers must be taken into account. Thus, the dynamic constants themselves may differ.

The molecule simulation has been used for the qualitative evaluation of the electric charge density on the atom in an extraction reagent or the chemical properties of organic solvent and extraction equilibrium constant in the field of solvent extraction. ${ }^{5-8}$ There are only a few reports regarding simulation studies of the liquid-liquid extraction process, such as uranium extraction of water/chloroform system and nickel extraction of water/pentane system. ${ }^{9-12}$ For metal complexes, there are only a few force field files which include the potential energies between metal atoms and other atoms. This is the main reason why molecular dynamics is not used in the field of solvent extraction.

In this paper, we report MD calculations and force-field parameters relating to the extractability of alkali metal ions with spirobenzopyran as the extraction reagents (Figure 1). For the calculations we used extraction reagents whose stabilities in the aqueous and organic phases were discussed in the previous paper. ${ }^{13}$
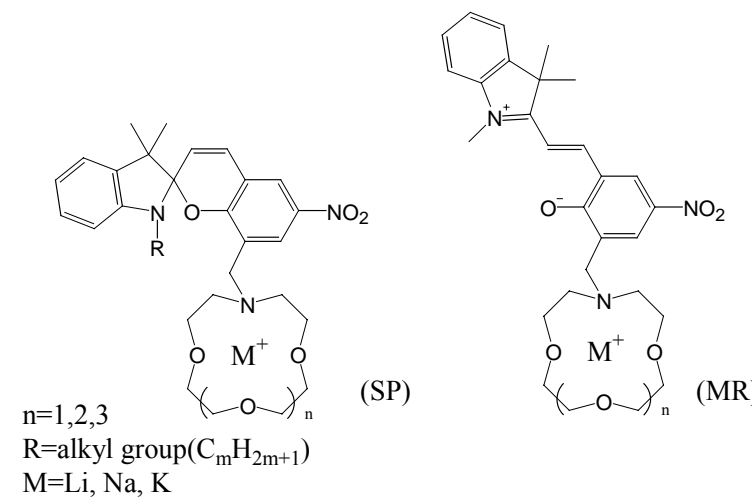

Figure 1. Chemical structure of the extraction reagent used in this study.

\section{Experimental}




\section{Preparation of Potential Energy File (Force Field File)}

For the MM calculation in the preparation of potential energy files, the molecular mechanics program MOMEC was used. As shown in Eq. (1), steric energy is the sum of the bond stretching energy $\left(E_{b}\right)$, valence angle energy $\left(E_{\theta}\right)$, torsion angle energy $\left(E_{\phi}\right)$, and nonbonded interaction (van der Waals force) energy $\left(E_{n b}\right)$. The above-described potential energy functions are expressed with Eqs. (2)-(8). In the equations, $k_{r}, k_{\theta}$, and $k_{\phi}$ are dynamic constants for bonding, valence angle, and torsion angle, and $\mathrm{r}_{0}, \theta_{0}$, and $\phi_{0}$ are the respective values in the free state where there is no restriction from the surrounding bonds; $r_{v d w}$ is the van der Waals radius of the atom, and $a, b, c$ and $\mathrm{m}$ are parameters. Energies for out-of-plane deformation, electrostatic interaction, and hydrogen bonding were ignored in the calculation. This approximation method was also used in the calculation by P. Comba et al. ${ }^{14}$ They created a potential file for lanthanoid metal ions in it, and the coworker computed the metal-ion selective extraction of lanthanoids by the molecular dynamics using the parameter. $^{15}$

$$
\begin{aligned}
& U_{\text {total }}=\sum\left(E_{b}+E_{\theta}+E_{\phi}+E_{n b}\right) \\
& E_{b}=1 / 2 k r\left(r_{i j k}-r_{0}\right)^{2} \\
& E_{\theta}=1 / 2 k_{\theta}\left(\theta_{i j}-\theta_{0}\right)^{2} \\
& E_{\phi}=1 / 2 k_{\phi}\left[1+\cos \left\{m\left(\phi_{i j k}+\phi_{0}\right)\right\}\right] \\
& E_{n b}=a e^{-b r_{i j}}-c r_{i j}^{-6} \\
& a=2.01 \times 10^{-15}\left(\varepsilon_{i} \varepsilon_{j}\right)^{1 / 2} \\
& b=1.25 \times 10^{11} /\left(r_{v d W_{i}}+r_{v d W_{j}}\right) \\
& c=1.77 \times 10^{44}\left(\varepsilon_{i} \varepsilon_{j}\right)^{1 / 2}\left(r_{v d W_{i}}+r_{v d W_{j}}\right)^{6}
\end{aligned}
$$

A model from the Cambridge Structural Database (CSD) was used as the reference model. We determined the root mean squares (RMS) of this model and the model obtained by calculation. The RMS is the square root of the average of the sum of squares of the corresponding interatomic distances when two models (CSD model and the model obtained by calculation) are superimposed, and is an indicator of the consistency of the molecular structures. In the present calculation, each $k$ value was determined so that the RMS became a minimum.

\section{Calculation of Steric Energy in the Solvent}

To obtain the steric energy by MD calculation, the Fujitsu WinMasphyc 2.0 Pro program was used. Water and 1,2-dichloroethane (DCE) were used as solvents. For the calculation, a cube of side $25 \AA$ was used as a cell. The solvent cell was prepared with 256 water molecules and 119 DCE molecules to obtain the predetermined density. The unit cell was prepared by carrying out a structure relaxation calculation with the NVT ensemble (constant volume and temperature), a cell size adjustment calculation with the NTP ensemble (constant temperature and pressure), and the main calculation with the NVT ensemble.

The calculation of steric energy was performed in the following way. The initial model was prepared by inserting a metal-complexed extraction reagent into the unit cell at an arbitrary angle. For the initial structure of the inserted extraction reagent, we used the most stable structure calculated with the semi-empirical molecular orbital program MOPAC (PM3). The starting model for MD calculation was created based on the value of the electric charge and structure which was obtained by the MOPAC calculation. The calculation for this initial model was carried out with the NVT ensemble. On this occasion, Nose Hoover was used for a temperature control. The time intervals for the calculation was $1 \mathrm{fs}$ and the run time was 100 ps. Our own potential energy file was used for metal atoms, and the "Organic" and "Dreiding" files, which were attached to the program, were used for the calculation of intramolecular and intermolecular potential energies under the periodic boundary condition. ${ }^{16-20}$ For the calculated model, $\mathrm{U}_{\text {solv }}$ (internal energy for the solvent only), $\mathrm{U}_{\text {ext }}$ (internal energy for the extraction reagent only), and $\mathrm{U}_{\text {total }}$ (total internal energy) were determined. The steric energy for the metal-complexed extraction reagent in each solvent ( $\mathrm{U}_{\text {in phase }}$ ) was calculated according to the following equation: ${ }^{15}$

$$
\mathrm{U}_{\text {in phase }}=\mathrm{U}_{\text {solv }}+\mathrm{U}_{\text {ext }}-\mathrm{U}_{\text {total }}
$$

In addition, the steric energy difference between the aqueous and the organic phases was determined, and this was defined as the steric energy change $(\Delta U)$.

$$
\Delta \mathrm{U}=\mathrm{U}_{\text {water }}-\mathrm{U}_{\text {organic }}
$$

\section{Results and Discussion}

\section{Force-field parameters for alkali metal ion complexes}

Force-field parameters for the interaction between 
the crown ether and the complexed alkali metal ions are shown in Tables 1-4. The difference between the structure obtained by the calculation using optimized $\mathrm{k}$ values and the reference CSD structure was small. All the RMS were all within $0.2 \AA$, being a good result (Figure 2).

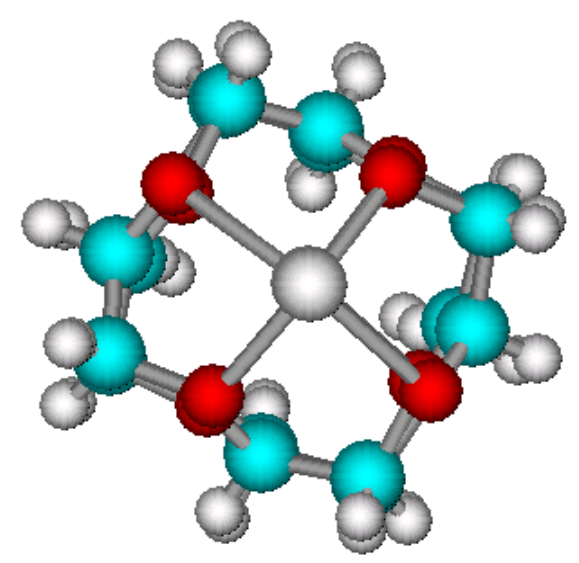

Figure 2. RMS overlay of calculated MOMEC and CSD structures of 12-crown-4 ether containing a lithium ion $(\mathrm{RMS}=0.1876)$.

Table 1. Bond Length Parameters.

\begin{tabular}{lll}
\hline Bond type & $\mathrm{k}_{\mathrm{r}}\left[\right.$ mdyn $\left.\AA^{-1}\right]$ & $\mathrm{r}_{0}[\AA]$ \\
\hline Li-O & 0.447 & 2.216 \\
$\mathrm{Na}-\mathrm{O}$ & 0.286 & 2.490 \\
K-O & 0.269 & 2.767 \\
\hline
\end{tabular}

Table 2. Valence Angle Parameters.

\begin{tabular}{lll}
\hline Angle type & $\mathrm{k}_{\theta}\left[\mathrm{mdyn} \cdot \mathrm{rad}^{-1}\right]$ & $\theta_{\mathrm{O}}[\mathrm{rad}]$ \\
\hline Li-O-C & 0.001 & 1.985 \\
O-Li-O & 0.056 & 1.814 \\
Na-O-C & 0.011 & 1.900 \\
O-Na-O & 0.168 & 2.055 \\
K-O-C & 0.049 & 1.760 \\
O-K-O & 0.059 & 1.431 \\
\hline
\end{tabular}

Table 3. Torsion Angle Parameters.

\begin{tabular}{cclc}
\hline Torsion type & $\mathrm{k}_{\phi}\left[\mathrm{mdyn} \cdot \mathrm{rad}^{-1}\right]$ & $\mathrm{m}$ & $\phi_{\mathrm{o}}[\mathrm{rad}]$ \\
\hline$* *-\mathrm{O}-\mathrm{Li}-* *$ & 0.0073 & 2 & 1.571 \\
$* *-\mathrm{O}-\mathrm{Na}-* *$ & 0.0068 & 2 & 1.571 \\
$* *-\mathrm{O}-\mathrm{K}-* *$ & 0.0056 & 2 & 1.571 \\
\hline
\end{tabular}

** indicates any atom.
Table 4. Nonbonded Interaction Parameters.

\begin{tabular}{lll}
\hline Atom & $\mathrm{r}_{\mathrm{vdW}}[\AA]$ & $\varepsilon[-]$ \\
\hline $\mathrm{Li}$ & 1.550 & 0 \\
$\mathrm{Na}$ & 1.900 & 0 \\
$\mathrm{~K}$ & 2.270 & 0 \\
\hline
\end{tabular}

The $\mathrm{k}$ values obtained were converted for MD use and used as parameters.

\section{Steric energy and stability of extraction reagent}

The spirobenzopyran ring is cleaved on exposure to light; therefore, two isomers are present in the solvent extraction process, SP (closed ring) and MR (open ring) (Figure 1).

The steric energies of the extraction reagent complexed with sodium ions in the aqueous phase and organic phase are shown (Figures 3 and 4) with respect to the different structures.

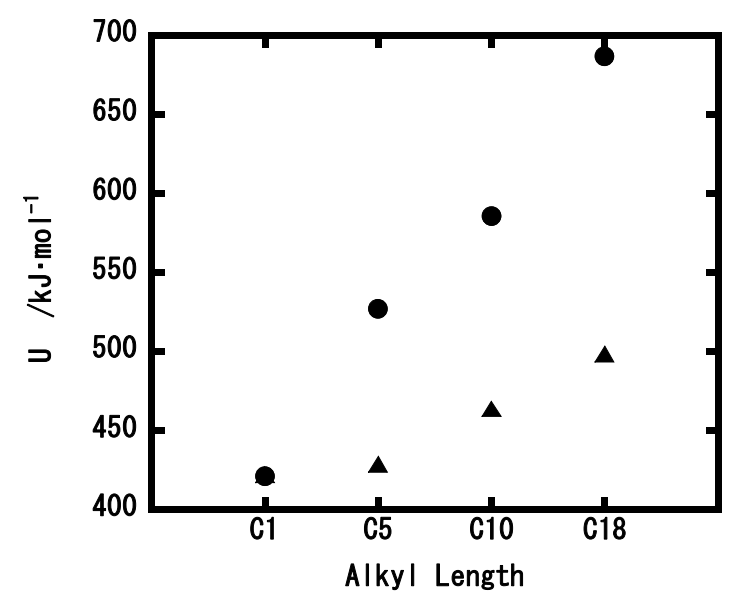

Figure 3. Steric energy of 12-crowned spirobenzopyrans complexed with sodium ions in the aqueous phase ( $\bullet$ : SP form, $\boldsymbol{\Delta}$ : MR form).

The longer the alkyl-group of the spirobenzopyran is, the longer the steric energy is, but increases only slightly in the organic phase. Accordingly, the difference between these two energies $(\Delta U)$ increases with the increase in the chain length. This means that the complexed extraction reagent in the aqueous phase becomes unstable with the increase in the chain length of the alkyl group, while its stability hardly changes in the organic phase. As the complexed extraction reagent is 
more stable in the organic phase, it is more easily extracted into the organic phase. A similar tendency was also recognized in the uncomplexed model. However, the steric energy of the metal complex for the aqueous phase does become smaller due to the manifestation of the polarity.

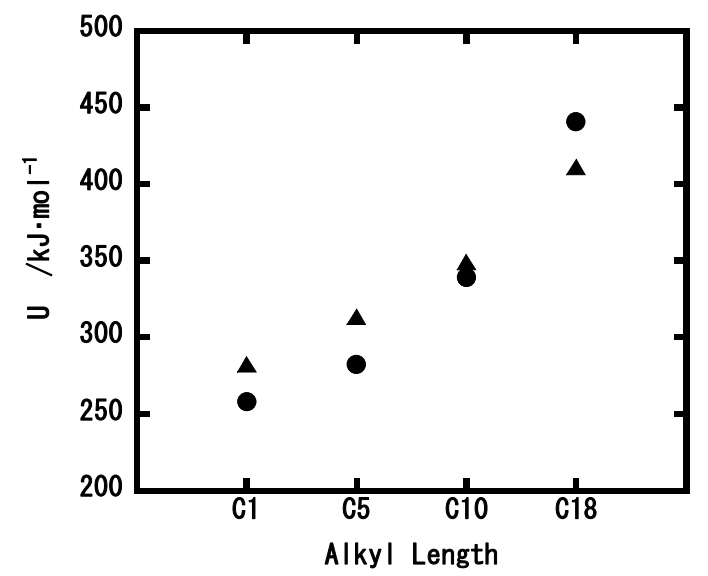

Figure 4. Steric energy of 12-crowned spirobenzopyrans complexed with sodium ions in the organic phase $(\bullet$ : SP form, $\boldsymbol{\Delta}$ : MR form).

When the SP form and the MR form of the extraction reagent are compared with the regard to the steric energy, it can be seen that the steric energy of the MR form is smaller than that of the SP form in the aqueous phase, while the steric energy of the SP form is smaller than that of the MR form in the organic phase. This is explained by the fact that the MR form has a dipolar structure and that the electric charge is localized. Thus, the steric energy is small in the aqueous phase and large in the organic phase. The same tendency was observed when the complexes of lithium or potassium ions were used.

It is possible that the steric energy changes with the change in the size of the crown ether ring. However, due to the steric energy is related to the conformability with the crown ether cavity size and a metal ion radius, It will be discussed in detail later.

The enthalpy term is one of the most important terms in a discussion of energy. The present calculation, however, was carried out using the NTV ensemble- that is, at a constant temperature-so we assumed that the enthalpy term could be ignored because it was adiabatic.

Next, the steric energy of the complexed extracting agent was calculated for each metal ion. When the extraction reagent is used for two-phase liquid-liquid extraction, various process routes are possible, but in the end the metal-complexed extraction reagent returns to the organic phase in the MR form. Therefore, the extractability of the complexed reagent is related to the steric energy of the MR form (Scheme 2). For this calculation, an octadecyl group with high extraction efficiency was used as the alkyl group on the spiropyran ring. The differences in steric energy $(\Delta U)$ between the extraction reagent complexed with an alkali metal ion in the aqueous phase and the same complexed reagent in the organic phase are shown in Figure 5.

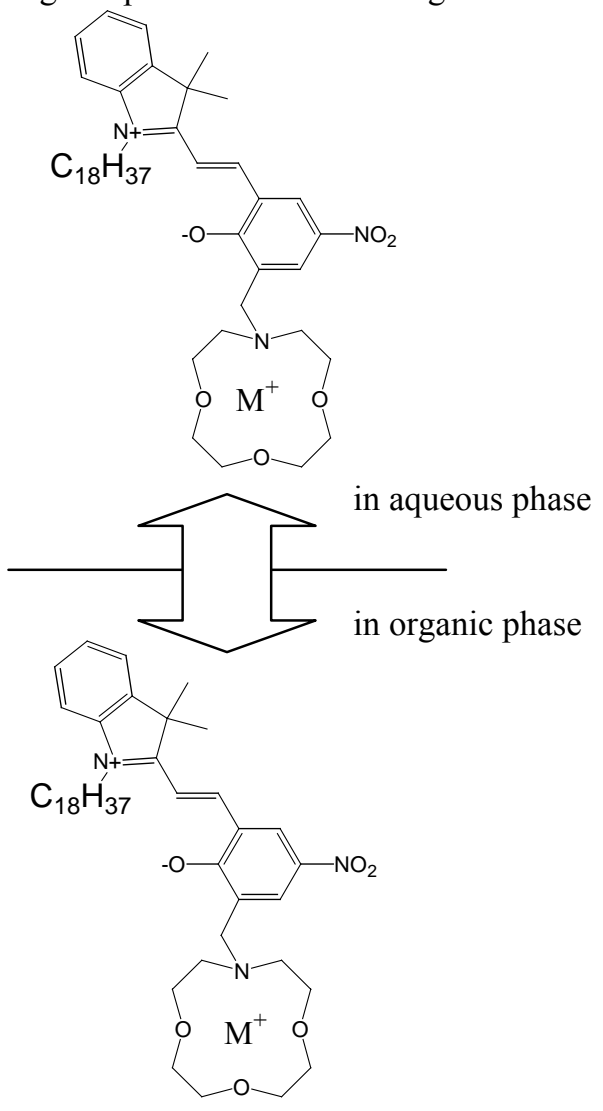

Scheme 2. Calculation models of extraction reagent.

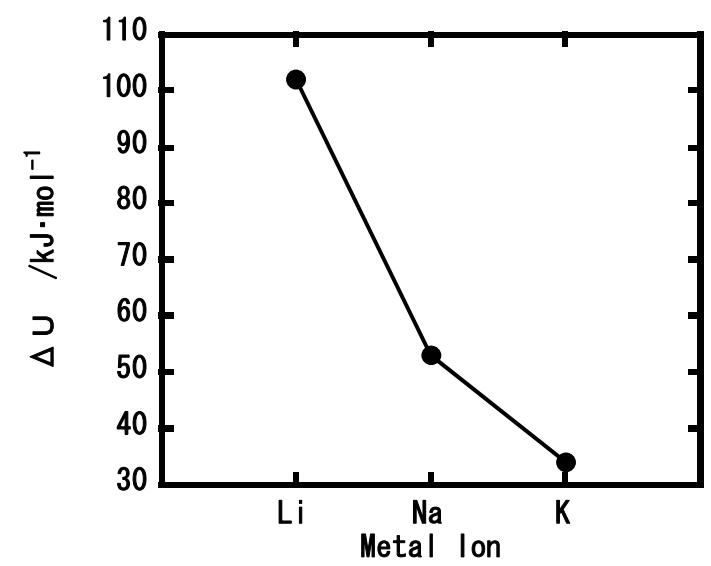

Figure 5. Differences in steric energy between aqueous and organic phases for 12-crowned ligand (MR form) complexed to various alkali ions. 
The differences in steric energies between in the aqueous phase and in the organic phase are considerable, indicating the higher stability of the complexed extraction reagent in the organic phase. For the extraction reagent containing a 12-crown ether moiety, the difference is the highest when the reagent is complexed with a lithium ion. It indicas that this complex is the most easily extracted to the organic phase. The experimental results for this extraction are shown in Figure 5. In the extraction experiment, a $1 \times 10^{-2} \mathrm{M}$ aqueous solution of alkali metal hydroxide (aqueous phase) was mixed with a $1 \times 10^{-3} \mathrm{M}$ 1,2-dichloroethane solution of the extraction reagent (organic phase). UV-light was irradiated to the mixture for $10 \mathrm{~min}$ and then the organic phase was separated. The UV-vis absorption spectra of the organic phases for various metal ions are shown in Figure 6.

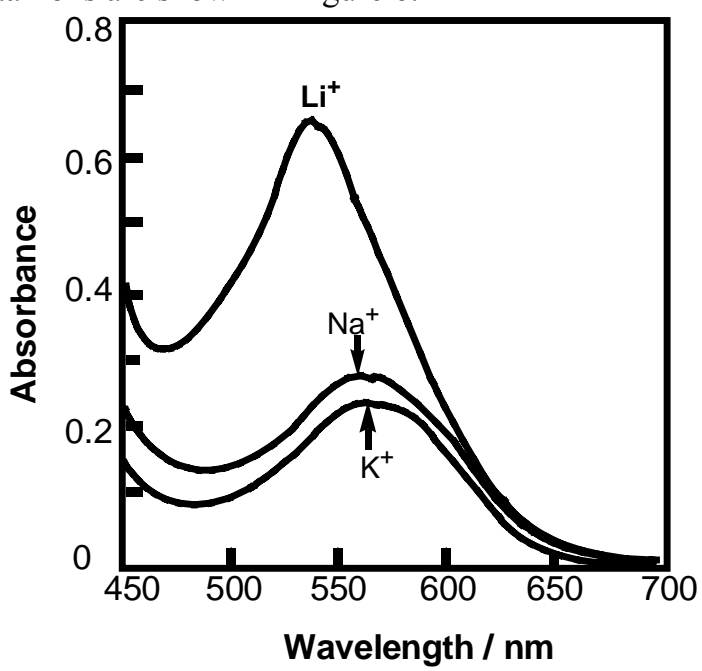

Figure 6. Absorption spectra of organic phases in the liquid-liquid extraction of alkali metal ions using a 12-crowned reagent under UV irradiation conditions.

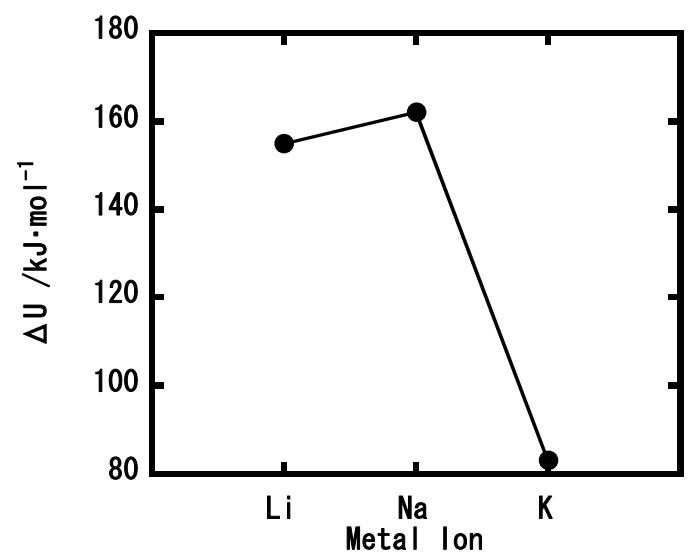

Figure 7. Differences in steric energies between organic and aqueous phases for 15-crowned ligand (MR form) containing various alkali ions.
In the absorption spectra, the absorption peak around $550 \mathrm{~nm}$ is attributable to the MR form of the extraction reagent. A larger peak indicates that the larger amount of the complexed extraction reagent has changed to the MR form and returned to the organic phase. Thus, this peak exhibits extractability of the metal ion complex. The calculated results and the measured results show a similar tendency of the order of metal ions in magnitude correlation, which indicates the validity of the calculated results. The calculated and measured results for the extraction reagent with 15-crown ether and 18-crown ether moieties are shown in Figures 7-10.

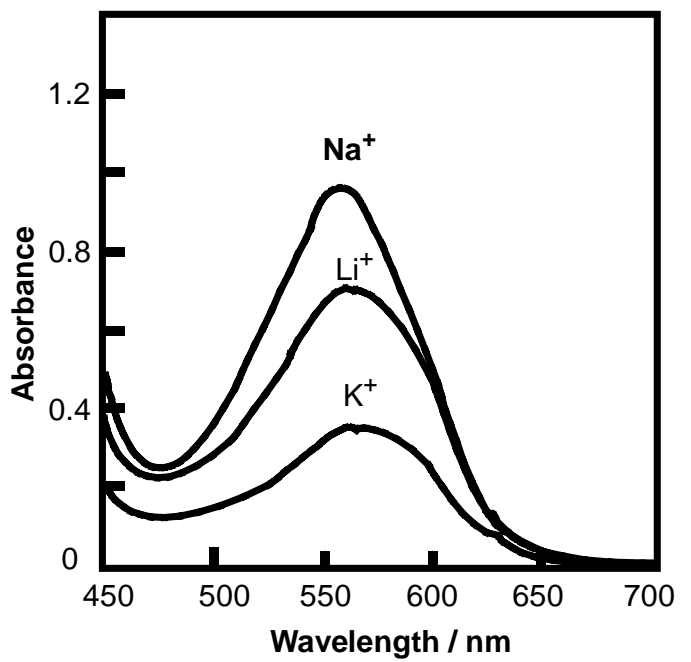

Figure 8. Absorption spectra of organic phases in the liquid-liquid extraction of alkali metal ions using a 15-crowned reagent under UV irradiation conditions.

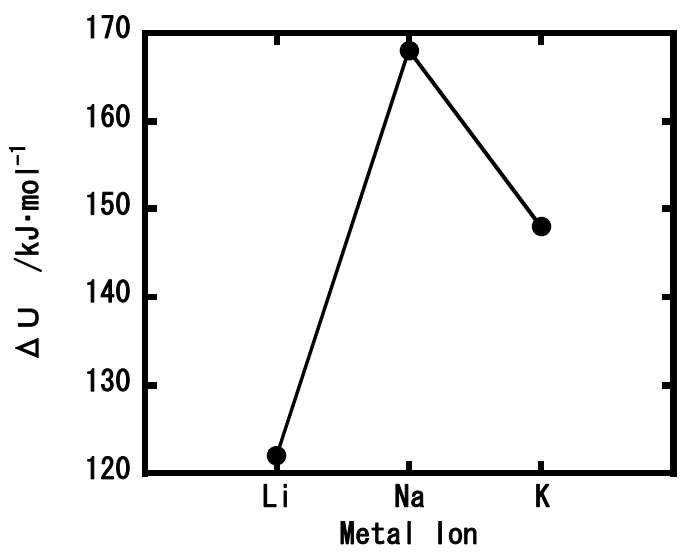

Figure 9. Differences in steric energies between organic and inorganic phases for 18-crowned ligand (MR form) containing various alkali ions. 


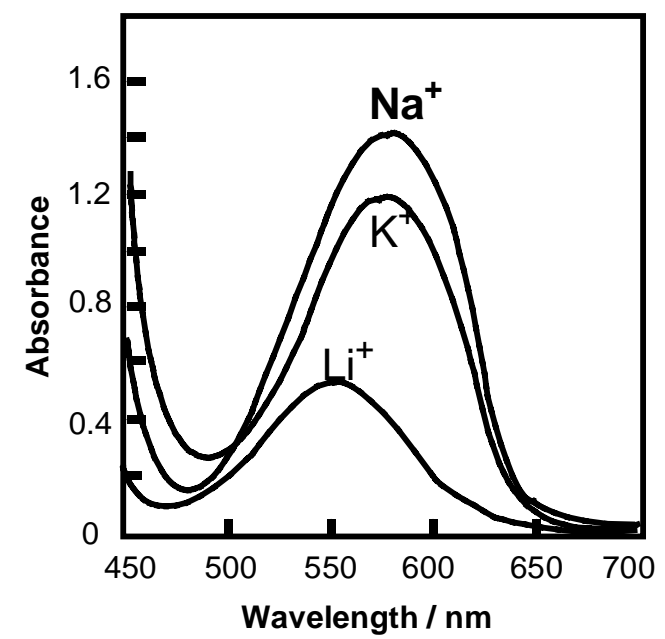

Figure 10. Absorption spectra of organic phases in the liquid-liquid extraction of alkali metal ions using an 18-crowned reagent under UV irradiation conditions.

It is well known that 15 -crown-5 and 18 -crown-6 derivatives form stable complexes with sodium and potassium ion, respectively, to extract their complexes into the organic phase selectively. The 18-crown spirobenzopyran, however, the most extract $\mathrm{Na}^{+}$not $\mathrm{K}^{+}$. For such a characteristic phenomenon of crowned spirobenzopyran, the calculated results and measured results were consistent in the order of metal ions with respect to stability of metal complex in the organic phase. Thus, the measured results were supported by the calculated results. A comparison between these calculated results and the measured extractabilities of the metal ions is shown in Figures 11-13.

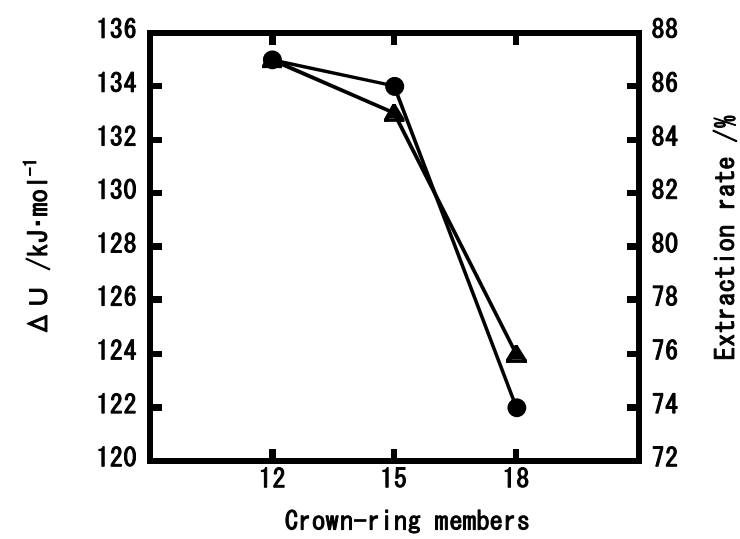

Figure 11. $\Delta \mathrm{U}$ compared to actual extractability for $\mathrm{Li}^{+}$, with respect to crown ring size.

$(\boldsymbol{\Delta}$ : Extraction rate, $\mathbf{O}: \Delta \mathrm{U})$

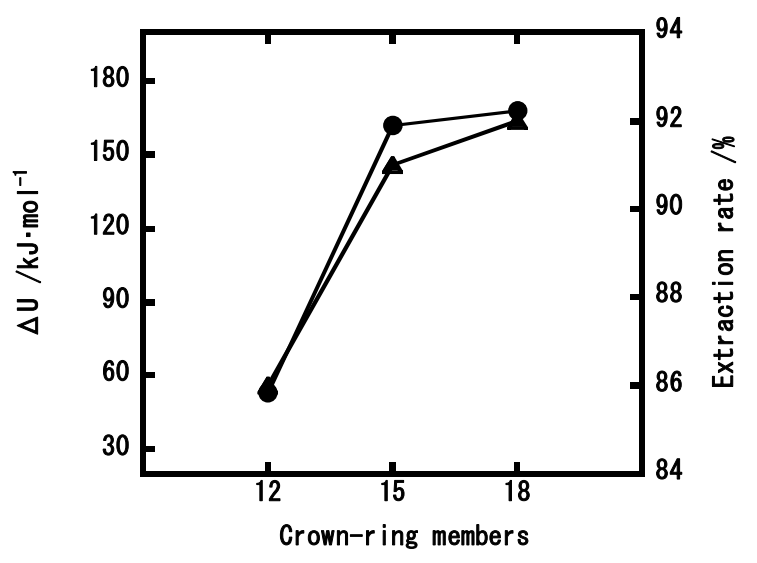

Figure 12. $\Delta \mathrm{U}$ compared to actual extractability for $\mathrm{Na}^{+}$, with respect to crown ring size.

$(\boldsymbol{\Delta}$ : Extraction rate, $\mathbf{O}: \Delta \mathrm{U})$

Crown ether derivatives generally exhibit the unique metal ion selectivity with respect to crown-ether ring size. This is because the extraction reagent forms a stable complex with the metal ion that matches the cavity size of its crown ether ring. These characteristics can be also be explained by the calculated results. The calculated $\Delta \mathrm{U}$ shows a similar trend to the actual change in extractability; the calculated results agree with the measured results well.

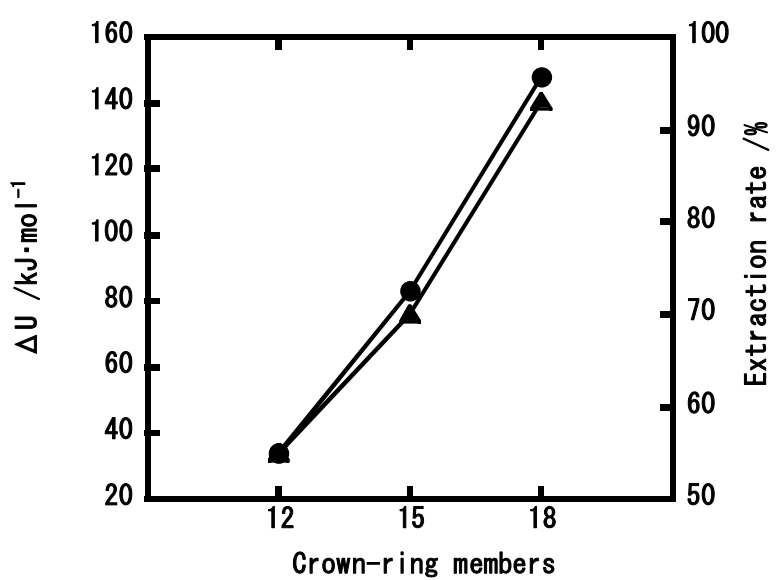

Figure 13. $\Delta \mathrm{U}$ compared to actual extractability for $\mathrm{K}^{+}$, with respect to crown ring size.

$(\boldsymbol{\Delta}$ : Extraction rate, $\mathbf{O}: \Delta \mathrm{U})$ 


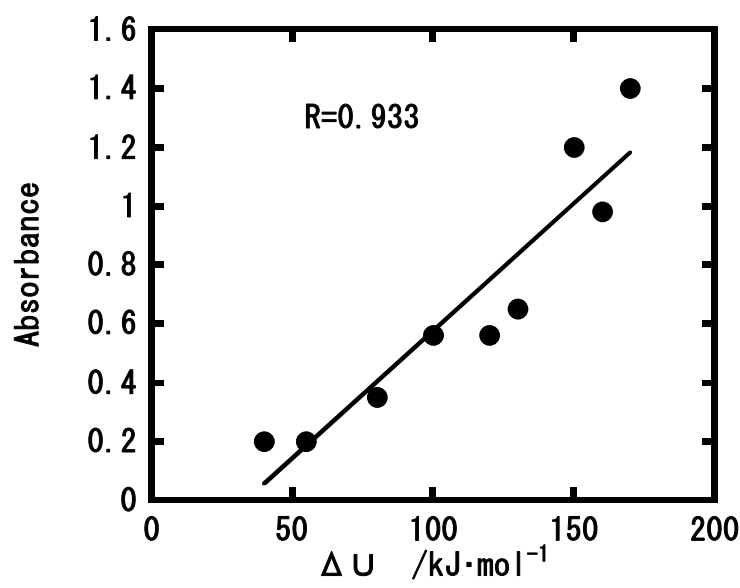

Figure 14. $\Delta \mathrm{U} v s$. absorbance of extraction reagent.

Regardless of the metal species and crown ring size, the calculated $\Delta \mathrm{U}$ and the measured absorbance displayed the relationship shown in Figure 14.

Some correlation was observed between the calculated $\Delta \mathrm{U}$ and the measured absorbance $(\mathrm{R}=0.933)$.

The above results suggest that the extractability of an unknown sample can be predicted by calculation.

\section{Summary}

A two-phase solvent extraction of alkali metals (Li, $\mathrm{Na}$, and $\mathrm{K}$ ) with spirobenzopyrans possessing a crown ether moiety was simulated by molecular dynamics modeling, using DCE as the organic phase. For all metal ions, stability in the organic phase increased as the increase in the length of the linear alkyl group attached to the spirobenzopyran moiety.

In the metal-complexed model, the most stable metal species varied according to the size of the crown ether ring, because stable metal complexes are formed between metal ions and crown ether rings of similar size. The tendency of extractability derived from the calculated results was similar to the tendency observed for the measured values. Thus, we were able to predict the metal ion extractabilities of the extraction reagents by calculation. In addition, the variation in the steric energy difference between phases $(\Delta U)$ under different conditions obtained from the calculated results was similar to the change in extractability. We conclude that it is possible to predict, to a certain extent, the extractability of an unknown sample by calculation. This may become a useful tool for molecular design of extraction reagents.

\section{References}

[1] K. Kimura, T. Yamashita, M. Yokoyama, J .Chem. Soc., Perkin Trans.2, 613-619(1992)

[2] K. Kimura, T. Yamashita, M. Yokoyama, J. Phys. Chem., 96, 5614-5617(1992)

[3] K. Kimura, T. Utsumi, T. Teranishi, M. Yokoyama, H. Sakamoto, M. Okamoto, R. Arakawa, H. Moriguchi, Y. Miyaji, Angew.Chem.Int.Ed.Engl.,36,2452-2544(1997)

[4] H. Sakamoto, T. Yokohata, T. Yamamura, K Kimura, Anal. Chem., 74, 2522-2528(2002)

[5] A. M. Rozen, B. V. Krupnov, Russian Chem.Rev.,65,973(1996)

[6] H. Stephan, K. T. Gloe, C. Chartroux, R. Neuman, E. Weber, A. Moeckel, N. Woller, G. Subklew, M. J. Schwuger, Solvent Extr.Res.Dev.,Jpn., 3, 43(1996)

[7] T. Krüger, K. Gole, H. Stephan, B. Habermann, K.Hollmann, E.Weber,J.Mol.Model., 2, 386(1996)

[8] A. H. Meniai, D. M. T. Newshm, Chem. Eng. Res. Des., 74, 695(1996)

[9] R. C. Gatrone, E. P. Horwitz, Solvent. Extr. Ion Exch, 6, 937(1988)

[10] C. Sella, D. Bauer, Solvent. Extr. Ion Exch, 10, 579(1992)

[11] H. Watarai , M. Gotoh, N. Gotoh Bull. Chem. Soc. Jpn, 70,957-964(1997)

[12] M. Baaden, M. Burgard, G. Wipff J.Phys.Chem. B, 105, 11131-11141(2001)

[13] H. Iwamoto, H. Skamoto, K. Kimura, J. Comp. Aided Chem., 6, 37-42(2005)

[14] P. Comba, K. Globe, K. Inoue, T. Krüger, H. Stephan, K. Yoshizuka, Inorg. Chem. 37, 3310-3315(1998)

[15] K. Yoshizuka, Anal .Sci., 20, 761-765(2004)

[16] S. L. Mayo, B. D. Olafson, W. A. Goddard, J. Phys. Chem., 94, 8897(1990)

[17] W. L. Jorgensen, E. R. Laird, T. B. Nguyen, J. Tirado-Rives, J.Comp.Chem,94,206-215(1990)

[18] W. L. Jorgensen, J. M. Briggs, M. L. Contreras, J. Phys. Chem., 94,1638-1686(1990)

[19] J. Pranata, S. G. Wiershke, W. L. Contreras, J. Am. Chem. Soc., 113, 2810-2819(1991)

[20] W. L. Jorgensen, J. Tirado-Rives, J. Am. Chem. Soc., 110, 1657-1666(1998) 


\title{
分子動力学を用いたクラウン化スピロベンゾピランの金属 抽出能の評価
}

\author{
岩本仁志、坂本英文、木村恵一 ${ }^{*}$
}

和歌山大学システム工学部

和歌山市栄谷 930

\begin{abstract}
クラウンエーテル部位を有するスピロベンゾピランの液-液溶媒抽出における抽出能を分子動力学計算を 用いて評価した。スピロベンゾピラン環に導入したアルキル基は、長鎖のものを導入するほど有機相で安定 する傾向を示すことを既に報告しているが、金属イオン錯体モデルについても同様の傾向を示した。全体的 に、クラウン化スピロベンゾピランがアルカリ金属イオンと錯形成することにより、水相での立体エネルギ 一は減少したが、有機相に比べ高く、有機相での安定性が示された。更に、クラウンエーテルの環サイズの 違いにより安定となる金属種に違いが生じた。またこの傾向は、スピロベンゾピランを用いた溶媒抽出後の 有機相の紫外可視吸収スペクトルの結果とも一致した。このことは、分子動力学計算により求めた立体エネ ルギーから抽出剤の性質を予測することが可能であることを示している。
\end{abstract}

キーワード: スピロベンゾピラン、アルカリ金属イオン錯体、抽出、分子動力学計算、立体エネルギ 一、

\footnotetext{
*kkimura@sys.wakayama-u.ac.jp
} 